\title{
Zeroth Order Resonator Antenna Dual Frekuensi Menggunakan Metode Composite Right Left Handed- Tranmission Line
}

\author{
Andik Atmaja \\ Politeknik Kota Malang \\ Jl. Tlogowaru No 3 Kedungkandang Malang, (0341)754088 \\ andik.atmaja@gmail.com
}

\begin{abstract}
Abstrak - Pada penelitian ini telah didesain antena dual frequency sebagai perangkat untuk menangkap gelombang radio (RF) pada frekuensi $541 \mathrm{MHz}$ dan 2,4 GHz menggunakan metode Composite Right Left Handed-Tranmission Line (CRLH-TL). Metode ysng digunakan merupakan pengembangan dari struktur metamaterial dengan menghilangkan atau tidak menggunakan ground stub pada antenna. Hal ini dilakukan untuk mendapatkan dimensi antenna yang relative kecil. Parameter pengujian antenadual frekuensi ini meliputi return loss, VSWR, dan bandwidth. Nilai parameter return loss antenna pada frekuensi $541.730 \mathrm{MHz}$ sebesar $-31.92 \mathrm{~dB}$ sedangkan pada frekuensi $2.4207 \mathrm{GHz}$ sebesar -27.86 . VSWR hasil pengukuran antenna frekuensi $541.730 \mathrm{MHz}$ memiliki nilai 1.038 sedangkan pada frekuensi 2.420 $\mathrm{GHz}$ sebesar 1.115. Pada frekuensi $541.730 \mathrm{MHz}$ memiliki bandwidth sebesar $39.980 \mathrm{MHz}$, sedangkan pada frekuensi $2.420 \mathrm{GHz}$ memiliki bandwidth sebesar $219.890 \mathrm{MHz}$.
\end{abstract}

Kata Kunci: Metamaterial, CRLH-TL, return loss, VSWR

\section{Pendahuluan}

Penggunaan antenna pada masa sekarang menjadi salahsatu bagian yang tidak terpisahkan dari perlatan telekomunikasi, terutama peralatan wireless yang sekarang berkembang pesat saat ini. Peralatan dan perangkat wireless yang berkembang saat ini seperti komunikasi celluler, WIFI, Bluetooth, radio dan televisi tidak lepas dari antenna. Untuk satu perangkat telekomunikasi membutuhkan minimal satu antena, maka jika suatu alat memiliki dua perangkat telekomunikasi maka membutuhkan dua antenna. Untuk menyederhanakan perangkat agar lebih effisien maka digunakan antenna dual frekuensi, sehingga untuk satu antenna dapat bekerja pada dua perangkat yang berbeda.

Antenna dual frekuensi yang dirancang pada penelitian ini bekerja pada frekuensi 541 $\mathrm{MHz}$ dan 2,4 GHz. Frekuensi $541 \mathrm{MHz}$ digunakan untuk perangkat televisi dan $2.4 \mathrm{GHz}$ digunakan untuk perangkat WIFI. Antenna dirancang menggunakan metode Zeroth Order Resonator dengan pendekatan Composite Right Left Handed-Tranmission Line (CRLH-TL).

Metamaterials yang di sebut juga artificial material atau Left Handed material (LH) merupakan struktur elektromagnetik buatan yang effectively homogeneous dengan sifat yang tidak biasa dan tidak tersedia di alam [1], misalkan pada material Double Negative (DNG) yang memiliki $\mu$ negatif dan $\varepsilon$ negatif. Dengan merubah beberapa propertis pada sebuah material seperti $\mu$ dan $\varepsilon$, dapat digunakan untuk merekayasa sifat elektromagnetik, sifat gelombang dan sifat optik bahan. Dengan memanipulasi sifat-sifat tersebut bisa didapatkan

TELKA, Vol.4, No. 2, November 2018, pp. 114 120

ISSN (e): 2540-9123

ISSN (p): 2502-1982 
penurunan yang signifikan dari dimensi komponen (miniaturized), peningkatan kinerja komponen, atau menghasilkan komponen dengan sifat khusus [1][2].

Perancangan metamaterial dapat dilakukan dengan beberapa pendekatan yaitu pendekatan resonan dan pendekatan saluran transmisi. Model saluran transmisi yang pertama adalah Right Handed Transmission lines (RH TL) yang dimodelkan dalam sebuah unit sel sebagai rangkaian induktor seri(LR) dan kapasitor shunt (CR), yang kedua adalah Left Handed Transmission Line (LHTL) dimodelkan dalam sebuah unit sel sebagai rangkaian kapasitor seri (CL) dan induktor shunt (LL). Saluran transmisi CRLH dimodelkan dalam sebuah unit sel sebagai rangkaian kapasitor seri (CL), induktor seri (LR) dan induktor shunt (LL) serta kapasitor shunt (CR). Saluran transmisi CRLH memiliki konstanta propagasi positif, negatif dan nol sesuai dengan karakteristik dari permitivitas efektif dan permeabilitas[1].

Kelebihan dari Composite Right-left Handed Transmission Line (CRLH- TL) adalah strukturnya yang homogenous dimana struktur homogenous adalah struktur yang rata-rata strukturnya lebih kecil dari panjang gelombang pemandu, selain itu CRLH-TL dapat bekerja pada daerah broadband dengan rugi- rugi (looses) yang kecil. Dimensi dari struktur sebuah komponen dapat didesign hingga $1 / 4 \lambda$, sehingga memungkinkan miniaturized pada struktur CRLH [3][4].

\section{Metode Penelitian}

\subsection{Composite Right-Left Handed Transmission Line (CRLH-TL)}

Composite Right-Left Handed Transmission Line (CRLH-TL) adalah salah satu pendekatan yang digunakan dalam mendesign sebuah metamaterial. Karena MTMs adalah struktur yang effectively homogenous, maka MTMs pada dasarnya dapat dimodelkan oleh satu dimensi (1D) jalur transmisi, yang arah propagasinya mewakili setiap arah dalam material [1]. Rangkaian CRLH-TL merupakan gabungan antra RH-TL dan LH-TL, dalam sebuah unit sel CRLH terdiri dari rangkaian kapasitor seri (CL), induktor seri(LR) dan induktor shunt (LL) serta kapasitor shunt (CL)[6].

Penggambaran tentang metode Composite Right-left Handed Transmission Line (CRLHTL) dapat dijelaskan sesuai Gambar 1.

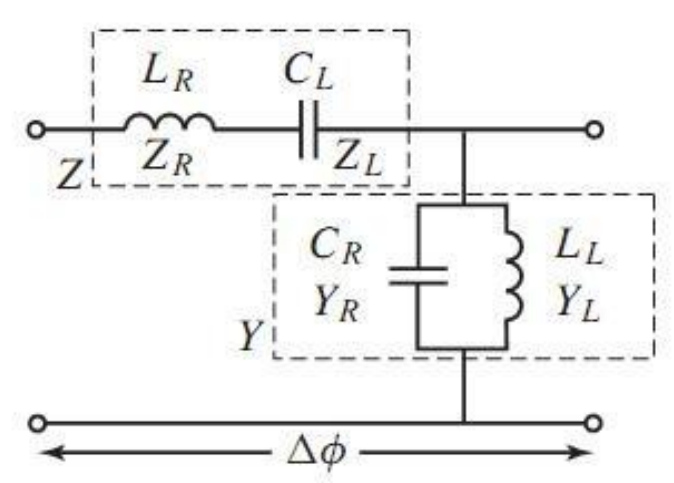

Gambar 1. Rangkaian asymmetris CRLH-TL [1]

Rangkaian CRLH dibagi menjadi 2 yaitu asymmetric dan symmetric unit cell. Pada Gambar 1 diatas adalah rangkaian CRLH asymmetric. Untuk rangkaian CRLH symmetris terdiri dari bentuk T(T-shape) dan bentuk phi ( $\pi$-shape) [6]. Rangkaian symmetris bentuk T merupakan pengembangan dari rangkaian CRLH asymmetris seperti ditunjukkan pada Gambar 2 


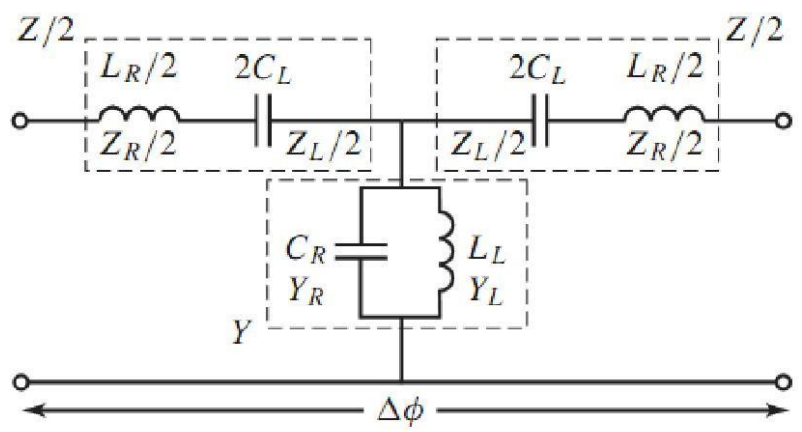

Gambar 2. Rangkaian symmetris CRLH-TL T-shape [1]

Rangkaian dasar CRLH TL seperti pada Gambar 2 terdiri dari rangkaian seri (impedansi, $\mathrm{Z}$ ) dan rangkaian shunt (admitansi, $\mathrm{Y}$ ), rangkaian seri terdiri dari Right handed inductor $\left(\mathrm{L}_{\mathrm{R}}\right)$ dan left handed capacitor $\left(\mathrm{C}_{\mathrm{L}}\right)$ sedangkan pada rangkaian shunt terdiri dari right handed capacitor $\left(\mathrm{C}_{\mathrm{R}}\right)$ dan left handedinductor $\left(\mathrm{L}_{\mathrm{L}}\right)$ maka persamaan rangkaian seri dan rangkaian shunt adalah [1]

$$
\begin{aligned}
& Z=j\left(\omega L_{R}-\frac{1}{\omega C_{L}}\right)=j \frac{\left(\omega / \omega_{s e}\right)^{2}-1}{\omega C_{L}} \\
& Y=j\left(\omega C_{R}-\frac{1}{\omega L_{L}}\right)=j \frac{\left(\omega / \omega_{s h}\right)^{2}-1}{\omega L_{L}}
\end{aligned}
$$

Persamaan resonansi rangkaian seri dan resonansi rangkaian shunt dalam persamaan impedansi dan admitansi didiskripsikan dalam persamaan berikut:

$$
\begin{aligned}
& \omega_{s e}=\frac{1}{\sqrt{L_{R} C_{L}}} \\
& \omega_{s h}=\frac{1}{\sqrt{L_{L} C_{R}}}
\end{aligned}
$$

Dengan variabel PRH dan PLH adalah

$$
\begin{aligned}
\omega_{R} & =\frac{1}{\sqrt{L_{R} C_{R}}} \\
\omega_{L} & =\frac{1}{\sqrt{L_{L} C_{L}}} \\
k=L_{R} C_{L} & +L_{L} C_{R}
\end{aligned}
$$

Dengan frekuensi transisi adalah

$$
\omega_{0}=\sqrt{\omega_{R} \omega_{L}}
$$

\subsection{Microstrip CRLH}

Kapasitor Interdigital dan stub pada implementasi CRLH pada satu sel unit ditunjukkan dalam Gambar 3. Rangkaian ekuivalen dari sel unit seri kapasitor interdigital dan induktor stub ditunjukkan dalam Gambar 3. kapasitor interdigital CRLH microstrip pada rangkaian lumped merupakan ekuivalen dari impedansi (Z), sedangkan stub pada rangkaian lumped merupakan ekuivalen dari admitansi (Y). Pada CRLH microstrip ada beberapa parameter yang muncul disebabkan oleh design kapasitor interdigital dan stub, namun dari beberapa parameter tersebut ada yang diabaikan karena sangat kecilnya nilai dari parameter tersebut [5]. 


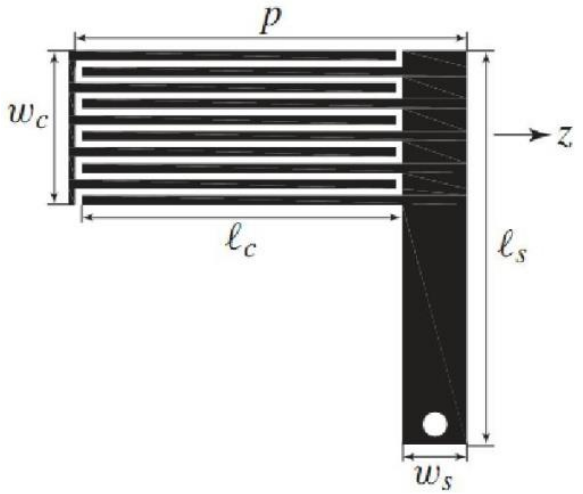

Gambar 3. Unit cell dari microstrip CRLH [1]

Dari Gambar 4 bisa didapatkan parameter-parameter yang digunakan dalam mendesain mikrostrip CRLH. Parameter scattering atau S parameter dari kapasitor interdigital dan induktor stub tersebut nilai dari parameter dirubah kedalam bentuk admittansi (Y) dan impedansi (Z) secara berurutan dan dikonversi dengan mengabaikan induktansi $\mathrm{L}_{\mathrm{s}}^{\mathrm{si}}$ yang sangat kecil, maka didapatkan parameter CRLH yaitu [1].

$$
\begin{gathered}
L_{R}=L_{s}^{i c} \\
C_{R}=2 C_{p}^{i c}+C_{p}^{s i} \\
L_{L}=L_{p}^{s i} \\
C_{L}=C_{s}^{i c}
\end{gathered}
$$

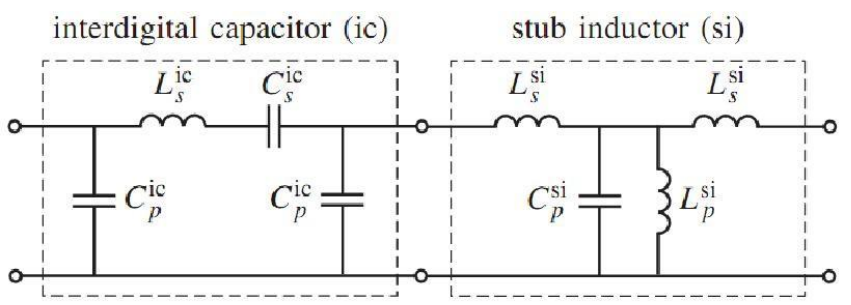

(a)

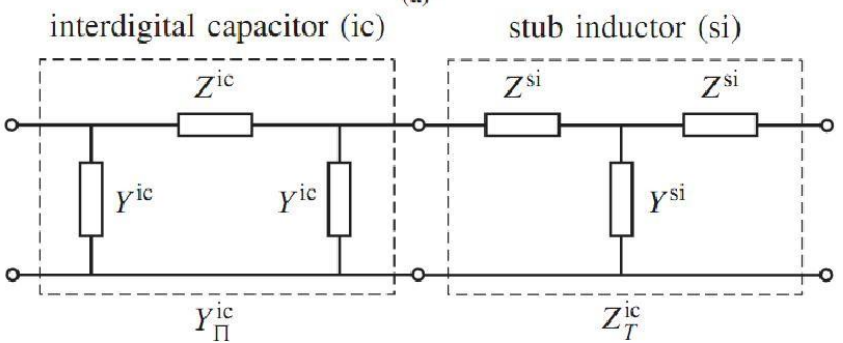

Gambar 4. Rangkaian eqivalen dari CRLH microstrip [1]

\section{Hasil dan Analisis}

\subsection{Desain Antena Ultra High Frequency}

Desain antena dual frekuensi yaitu pada frekuensi $541 \mathrm{MHz}$ dan 2,4 GHz dengan metode Composite Right Left Handed- Tranmission Line (CRLH-TL). Antenna menggunakan bahan substrat FR4 Epoxy dengan konstanta dielektrik $\left(\varepsilon_{\mathrm{r}}\right)$ sebesar 4,4 dengan ketebalan 1,6 mm dan dengan ketebalan tembaga $0,5 \mathrm{~mm}$.

Geometri antena mikrostrip Ultra High Frequency (UHF) pada frekuensi 2,4 dengan metode Composite Right Left Handed-Tranmission Line (CRLH-TL) seperti ditunjukkan pada Gambar 5. 


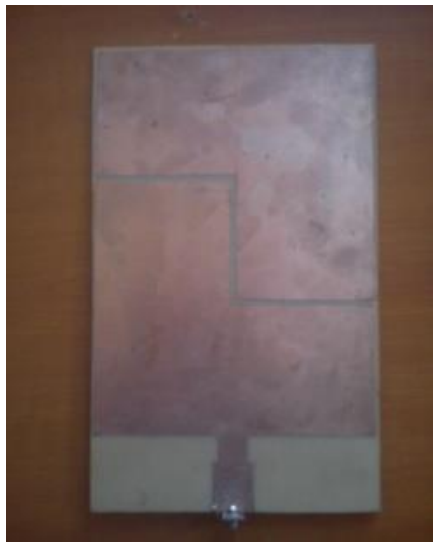

Gambar 5. Desain antena dual frekuensi pada frekuensi $541 \mathrm{MHz}$ dan 2,4GHz dengan metode Composite Right Left Handed- Tranmission Line (CRLH-TL)

Hasil dari desain ukuran geometri antena dual frekuensi pada frekuensi $541 \mathrm{MHz}$ dan 2,4GHz ditunjukkan pada Tabel 1 .

Tabel 1. Ukuran dimensi antena hexagonal single patch

\begin{tabular}{|l|r|}
\hline \multicolumn{1}{|c|}{ Keterangan } & \multicolumn{1}{c|}{$\begin{array}{c}\text { Ukuran } \\
(\mathbf{m m})\end{array}$} \\
\hline Panjang finger interdigital & $163.2 \mathrm{~mm}$ \\
\hline Lebar finger interdigital & $83.2 \mathrm{~mm}$ \\
\hline Panjang port & $50 \mathrm{~mm}$ \\
\hline Lebar port & $24 \mathrm{~mm}$ \\
\hline Panjang port Impedansi matching & $50 \mathrm{~mm}$ \\
\hline Lebar port Impedansi matching & $16 \mathrm{~mm}$ \\
\hline Jarak antar finger & $4 \mathrm{~mm}$ \\
\hline
\end{tabular}

\subsection{Hasil Pengukuran Antena Ultra High Frequency (UHF)}

Setelah dilakukan pengukuran terhadap desain antenna tersebut, didapatkan parameterparameter berikut:

\section{Return Loss}

Hasil pengukuran return loss dari antena mikrostrip hexagonal single patch dan patch array ditunjukkan pada Gambar 6.

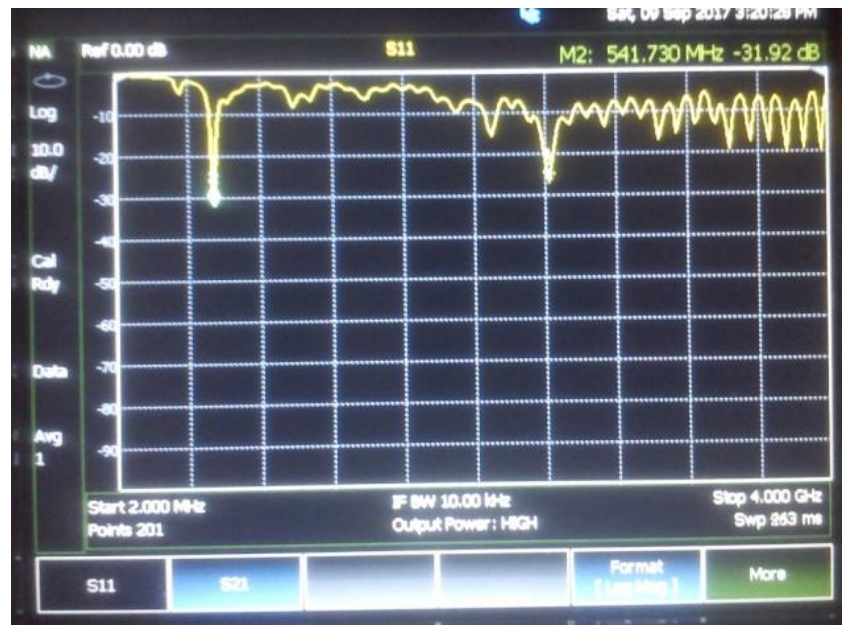

Gambar 6. Hasil pengukuran return loss antena dual frekuensi pada frekuensi $541 \mathrm{MHz}$ dan 2,4GHz 
Berdasarkan Gambar 6, hasil pengukuran dari antena dual frekuensi pada frekuensi $541 \mathrm{MHz}$ dan $2,4 \mathrm{GHz}$ didapatkan nilai return loss pada frekuensi $541.730 \mathrm{MHz}$ sebesar $-31.92 \mathrm{~dB}$ sedangkan pada frekuensi $2.4207 \mathrm{GHz}$ sebesar $-27.86 \mathrm{~dB}$. Nilai return loss dari antena tersebut berada jauh dibawah $-10 \mathrm{~dB}$ yang merupakan batas nilai minimum return loss yang artinya daya yang dipantulkan sangat sedikit dan mendekati kondisi yang match antara transmitter dan beban/antena.

\section{Bandwidth (BW)}

Range frekuensi antena dengan beberapa karakteristik disebut juga bandwidth, sesuai dengan standar yang telah ditentukan. Berdasarkan Gambar 6 dapat diketahui nilai bandwidth antenna, hasil pengukuran menunjukkan pada frekuensi $541.730 \mathrm{MHz}$ memiliki bandwidth sebesar $39.980 \mathrm{MHz}$, sedangkan pada frekuensi $2.420 \mathrm{GHz}$ memiliki bandwidth sebesar $219.890 \mathrm{MHz}$.

\section{VSWR (Volatge Standing Wave Ratio)}

VSWR adalah parameter untuk pengukuran dasar dari impedansi matching antena. Hasil pengukuran untuk tampilan VSWR adalah seperti Gambar 7.

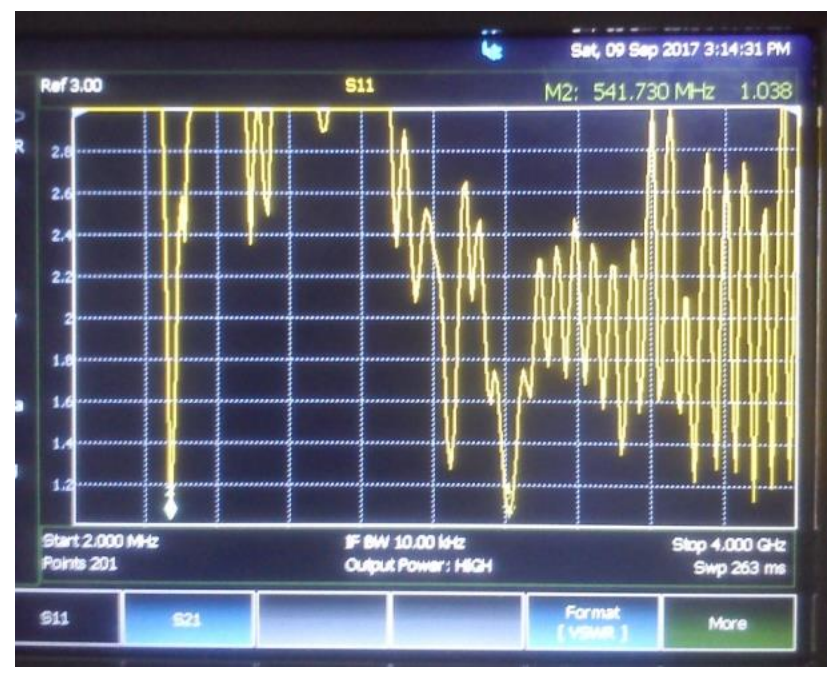

Gambar 7. Hasil Pengukuran VSWR

VSWR hasil pengukuran antenna frekuensi $541.730 \mathrm{MHz}$ memiliki VSWR 1.038 sedangkan pada frekuensi $2.420 \mathrm{GHz}$ memiliki VSWR 1.115. VSWR. hasil antena mikrostrip yang telah dibuat memenuhi syarat karakteristik karena memiliki nilai VSWR $<2$, artinya antena yang dibuat memiliki koefisien refleksi yang sangat kecil.

\section{Kesimpulan}

Kesimpulan dari penelitian menghasilkan:

1. Antenna yang dirancang menghasilkan dual frekuensi dengan frekuensi kerja frekuensi 541 $\mathrm{MHz}$ dan 2,4GHz.

2. dari antena dual frekuensi pada frekuensi $541 \mathrm{MHz}$ dan 2,4GHz didapatkan nilai return loss pada frekuensi $541.730 \mathrm{MHz}$ sebesar $-31.92 \mathrm{~dB}$ sedangkan pada frekuensi $2.4207 \mathrm{GHz}$ sebesar $-27.86 \mathrm{~dB}$.

3. bandwidth antenna pada frekuensi $541.730 \mathrm{MHz}$ memiliki bandwidth sebesar $39.980 \mathrm{MHz}$, sedangkan pada frekuensi $2.420 \mathrm{GHz}$ memiliki bandwidth sebesar $219.890 \mathrm{MHz}$

4. VSWR hasil pengukuran antenna frekuensi $541.730 \mathrm{MHz}$ memiliki VSWR 1.038 sedangkan pada frekuensi $2.420 \mathrm{GHz}$ memiliki VSWR 1.115. 


\section{Daftar Pustaka}

[1] C. Caloz dan T. Itoh. "Electromagnetic Metamaterials: Transmission Line Theory and Microwave Applications", WILEY-INTERSCIENCE, John- Wiley \& Sons Inc., Hoboken, NJ. 2006.

[2] R. Marqués, F. Martín, dan M. Sorolla, "Metamaterials with Negative Parameters: Theory, Design and Microwave Applications". New York: Wiley, 2008.

[3] A. Lai, C. Caloz, dan T. Itoh. September 2004. "Composite right/left-handed transmission line metamaterials", IEEE Microwave Magazine, vol. 5, No. 3, pp. 34-50.

[4] N. Engheta dan R. W. Ziolkowski. "Electromagnetic Metamaterials: Physics and Engineering Explorations", Wiley and IEEE Press2006.

[5] I. Bahl. "Lumped Elements for RF and Microwave Circuits", Artech House, Boston. 2003.

[6] Andik Atmaja, Herma Nugroho RAK. Desain Antena Zeroth Order Resonator dengan frekuensi kerja $2.4 \mathrm{GHz}$ untuk RF Harvesting Menggunakan Composite Right Left HandedTranmission Line (CRLH-TL), TELKA, UIN Sunan Gunung Djati. 2017. 